\title{
Leadership practice as antecedents of the teacher's performance in the City Division of Manila
}

Lacanin, Michelle E.

Legarda Elementary School and National University, Philippines (michellelacanin@yahoo.com) Astorga, Eriberto R., Jr.

De La Salle University, Eulogio Amang Rodriguez Institute of Science and Technology and National University, Philippines (Eriberto.astorga@dlsu.edu.ph)

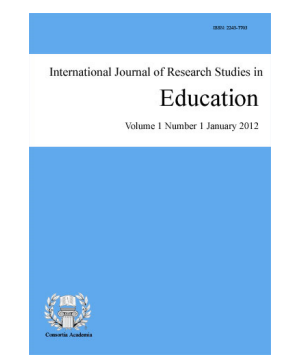

ISSN: 2243-7703 Online ISSN: 2243-7711

OPEN ACCESS

\section{Abstract}

Leadership practices are very important to lead an organization successfully. In school, leadership practices can be a factor to the teaching performance on their employee. The purpose of this study is to help the teachers to assess and reflect themselves on their leadership practices using the leadership inventory developed by James M. Kouzes and Barry S. Posner entitled "Leadership Practices Inventory (LPI)." This self-leadership practice inventory has five leadership practices known as Five Exemplary Models of Leadership Practices. This quantitative research describes the correlational relationship between the teacher's performance and the leadership practices. The teaching performance of the public elementary school teachers in the Division of City Schools of Manila was based on their Individual Performance Commitment and Review Form (IPCRF) in the school year 2018-2019. This research used a multi-stage sampling and purposive sampling to identify the sample population. A total of 176 public elementary teachers answered the leadership practices questionnaire. The key findings from this research is that the teachers can perform well even they do not often utilize the leadership practices and their ratings are not indicator in measuring the leadership practices of the teachers.

Keywords: antecedent, five exemplary models of leadership practices, individual performance commitment, review form, leadership enhancement program, teacher's performance 


\section{Leadership practice as antecedents of the teacher's performance in the City Division of Manila}

\section{Introduction}

Every organization has a leader who will and can lead the organization to attain and achieve its mission, vision and goal. The effectiveness and efficiency of the leader are needed to accomplish the common goal of the whole organization. In school, it needs a leader who will develop and improve the quality of education given to the students; and who will guide, inspire and motivate his or her co-workers. A good leadership equals a successful organization. But before a leader leads other; he must assess himself on his leadership practices. It is difficult to lead an organization because of the differences within the community: personalities, behaviors and values that they believed in. They must first believe in themselves that they can lead others and they can also lead themselves. Analyzing and understanding oneself is very important. It helps you as a leader to know your worth and the goal that you want to achieve. As a leader, knowing yourself and accepting yourself are very essential to lead others, it includes personal assessment and reflection to know the strengths and weaknesses of you. And in this process, the people around the leader, who knows them well, who interacts with them personally, and who supports them, as a leader, are needed in their self-discovery and self-awareness. These people will help the leader by giving and providing them honest insights and feedback for the improvement and effectiveness as a leader (Kouzes \& Posner, 2013).

A leader can connect, approach, influence, inform others. It is hard to achieve the goal of an organization without the help of others. A leader must know how to interact with people; how to be reachable and approachable to others. These people are very important to reach the common goal. Trust and the feeling of belongingness and love are needed to an organization so that they will perform well and respect you as their leader. In addition, a leader can inspire and motivate others to do things right and make things right. Being a leader, he or she must influence his or her people. He manages and leads others effectively and efficiently. Every leader has values that they believe in. They have different styles in leading others and the organization. These styles can affect the whole system and management of the organization (Nanjundeswaraswamy \& Swamy, 2014). For example, a leader must be ethical and emotional for them to gain respect and care for his or her people. Leadership is all about learning, from followers as well as others in leadership roles. Leaders should show a profound respect for the worth of every individual they encounter, and should integrate this practice into daily communication with fellow stakeholders. The results are likely to be positive for everyone involved.

And now, that the world changes very fast, new technologies are continuously invented and a lot of innovations are currently spreading out. These innovations are a big help to develop and improve different aspects of life especially in education. It progresses and enhances the quality of education that is needed today. Educational leaders must adapt these changes in terms of their leadership styles and practices (Rouse, 2005). The leadership practices must meet the needs of today's world to produce globally competitive students. And because of this, leaders must know their strengths and weaknesses for them to create leadership practices that are effective and ethical to suit the needs and fit the demands of the organization and also the students.

This study focuses on the relationship of the leadership practices of the teacher's antecedents to their teaching performance. The researcher is motivated to do this study to know and find ways to improve and develop the teachers' leadership practices. They will assess their leadership practices to develop and know more about their leadership; if it is suited to the people around them or not, and how it affects its teaching performance. The teachers play an important role in the teaching and learning process inside the school and also the success of the students. They are the ones who develop and influence the young minds of the students to face real life after school. Therefore, they must know the strengths and weaknesses of their leadership practices for them to provide the quality and effective education to the students. It is sought to answer the following questions: 
$>\quad$ What is the teacher's performance based on the Individual Performance Commitment Form (IPCRF) for School Year 2017-2018?

$>$ How do the leadership practices of the teachers describe using the Five Practices of Exemplary Leadership Model?

$>$ What significant relation exists between the Five Practices of Exemplary Leadership Model and teaching performance?

$>$ Based on the findings of the study, what leadership enhancement program may be recommended to improve the leadership practices of the teachers.

\section{Literature Review}

\subsection{Leadership Practices}

Being a leader in a group has a lot of responsibility especially in a school wherein so many people, teachers, students, parents and others needed to manage and lead. Schools continuously provide a quality education to all and because of that, it needs to become a good learning organization. The leadership effectiveness depends on how the leader influences the organization. The school leaders play an important role in the development of an organization. To achieve this, recruitment, development and retention of teachers and the students' outcome must be strengthened by the school leaders. To make this happen, there are factors to be considered such as teacher's satisfaction, school effectiveness, improvement, capacity, teacher leadership, distributive leadership, organizational learning and development (Mulford, 2003).

An effective school leader must consider the school and its people not only his personal interests and wants. The consideration of the whole stakeholders in all the decisions and actions that needs to be addressed is very important to make the school work harmoniously. The feeling of valued and belongingness in an organization can make people give their trust and loyalty to the organization. Knowing that they can share and contribute to the organization, they will remain and give their service to the school. Leadership is all about learning, from followers as well as others in leadership roles. Leaders should show a profound respect for the worth of every individual they encounter, and should integrate this practice into daily communication with fellow stakeholders. The results are likely to be positive for everyone involved.

Many teachers can become a leader. To become one of the teacher leaders, a wide range of roles must be considered to achieve and support the school and student success. Some of these are: (a) resource provider helps by sharing instructional materials; (b) instructional specialist helps in implementing effective teaching strategies; (c) curriculum specialist lead teachers to agree on standards, follow the adopted curriculum, use common pacing charts and develop shared assessment; (d) classroom supporter help in implementing new ideas to other teachers; (e) learning facilitator share and give facilitating professional learning opportunities among staff members; (f) mentor serves as a role model, acclimate and advise new teachers about instruction, curriculum, procedure, practices and more; (g) school leader serves and shares responsibilities for the success of the school; (h) data coach to use and share the information to strengthen instruction; (i) catalyst for change; and (j) learner who continuously improve and learn his or her learning and use it to help all students achieve. (Harrison and Killion, 2007).

\subsection{Five Practices of Exemplary Leadership Model}

Kouzes and Posner (2003), collected thousands of stories from the leadership experiences of the people from different places. Regardless of their differences in terms of their culture, gender, age and other factors, they have common leadership practices when they are at their personal best. These personal best leadership stories showed a similar pattern of behavior, and these are the five leadership practices that are common to all of them: Model 
the Way, inspire a Shared Vision, Challenge the Process, Enable Others to Act and encourage the Heart.

After three decades, the Five Practices of Exemplary Leadership Model continues proving its effectiveness in assessing the leadership practices of individuals, teams and organizations. These leadership practices are easy to learn and can be taught by anyone who wants to lead and accept the idea of leading others. The ongoing studies consistently confirm that Leadership Practices Inventory (LPI), one of the most widely used leadership assessment instruments, and the Five Leadership Practices are related to assess the effectiveness of the leaders and their commitment to leading others.

Model the Way - Leaders create standards to perform and be excellence in leading others and set examples for others to follow the way. They must model the expected behavior or standard to others if they want to gain commitment and respect from them. They must clarify values and behavior and be clear in guiding these principles (Kouzes and Posner, 2003).

Inspire a Shared Vision - Leaders have a vision or goals that they want to achieve for their organization. They have faith in these visions and believe that they can make extraordinary things happen. They enlist others in their common vision.

Challenge the Process - Leaders find ways and opportunities to change, improve, innovate and grow the status quo of the organization. To achieve this, they must experiment and take risks and welcome challenges (Kouzes and Posner, 2003). They must also accept the mistakes and disappointments while taking the risks and challenges. Leaders must not be afraid and openly admit that they made mistakes (Graybeal, 2015).

Enables Others to Act - In an organization, team effort and collaboration is required to achieve greatness. Leaders could not achieve the goals alone; they need the involvement of others. They must build trust and involve others in making decisions and make each person feel belonging and love. He lets and trusts others to accomplish the work.

Encourage the Heart - Leaders must recognize the contribution of others in achieving their vision. It is very hard, exhausting and frustrating for the organization to be on top. And the leader cannot do this alone without the help of his member. A leader must believe in the abilities and talents of others, appreciate and acknowledge the accomplishments they have done to the organization.

\subsection{Teacher's Performance in the Philippines}

Being a teacher is very hard especially in a third world country like the Philippines that needs a lot of support to give and provide an effective and good quality of education to its citizens. Many young minds depend on teachers who will help and develop them into a successful citizen of the country, but what if the teacher's performance is the problem. How can they help the students if they are not performing well?

According to the news article of the Manila Bulletin published last October 3, 2017, the Philippine Business for Education (PBEd), a non-profit and non-stock organization that aims to be the business community's response to the need for consensus and sustained advocacy in education reform, conducted a study on the Licensure Examination for Teacher (LET) performance of all the Teacher Education Institutions (TEI) in the Philippines and find out that the school performance in the teacher boards has been declining in the past nine years, from 2009-2017. The performances of the TEIs have been performing below the national passing rate.

The PBEd Director Love Basillote emphasized the need to improve the teachers' quality in the Philippines so that the students can be able to learn better. According to Basillote (2017), to improve the quality of the teachers in the country, various research and several programs for the education sector must be prioritized to develop teachers' performance. Because of the consistent declining of the teacher's performance and being not well equipped in teaching students, Basillote noted that after looking at the result of the National Achievement Test (NAT) result, the students have consistently below the target (Hernando-Malipot, 2017). 
The students' performance especially in their achievement test results has a significant relationship to the teacher's educational attainment. In this study, the teacher with a Bachelor's degree tends to have better performing students in NAT (Magsayo, 2009). The teacher's profile and achievements is one of the big factors to have a good teaching performance and because of this, it will result in a positive performance output of the students. Teachers with a good educational background and achievement can help the students better in their performance. They can facilitate and share knowledge to the students. The effective teachers can give substantial influence on the students' achievement and teachers who perform better and who are more involved with their students can help the students to perform better (Lazaro, 2011). By having a good relationship with students, teachers can offer to students' chances to be motivated and feel engaged in the learning process. Students will be engaged actively in the learning instead of being passive learners.

\subsection{Result-Based Performance Management System (RPMS)}

The Department of Education (DepEd) mandated a DepEd Order No. 2, s. 2015 entitled Guidelines on the Establishment and Implementation of the Result-Based Performance Management System (RPMS) in the Department of Education, signed by Br. Armin Luistro FSC, former DepEd Secretary. This DepEd Order was addressed to Undersecretary down to the Heads and Principal of Elementary and Secondary Schools and to other concerned personnel of the department. The DepEd Order aims to provide comprehensive guidelines for the adoption of the Civil Service Commission's (CSC) Strategic Performance Management System (SPMS) in DepEd. According to the DepEd Order, these guidelines stipulate the specific mechanism, criteria and processes for the performance target setting, monitoring, evaluation and development planning for schools and offices, covering all officials and employees, school-based and non-school-based, in the department holding regular plantilla positions. Personnel under contracts of service/job order and LGU-funded employees shall likewise be covered, but for purposes of performance evaluation only. The DepEd Order was aligned to the Department of Education's mandate, vision, mission and its core values, which is committed to continuously improve itself to better serve the Filipino learners and the community. It was created to make sure that the department or the organization performs efficiently and effectively and to track the individual improvement and growth of all the personnel. According to the DepEd Order, it is necessary to link the SPMS with the other systems relating to human resources and to ensure adherence to the principle of performance-based tenure and incentives.

In the DepEd Order Roman Numeral IV, Policy Statement, the department gave guidelines on the implementation of the RPMS in the Department of Education. It is to stipulate the strategies, methods, tools and rewards for assessing the accomplishments and their commitments. It will be also used for measuring and rewarding or granting the Performance-Based Bonus (PBB) to those school-based and non-school-based personnel who performed and showed efficiency and effectiveness in their work. The relationship of the leadership practices and teaching performance of the teachers is the main focus of this study. The declining of teacher's performance affects the student's performance and it will also affect the school's performance, and because of this, teachers must improve and develop their teaching skills and performance and one way to improve it is by identifying the strengths and weaknesses of their leadership practices and develop it to help not only the students but also the whole organization

\section{Methodology}

Content and Participant - In this study, the researcher made use of a descriptive correlation method of research to gather information in assessing the leadership practices of teachers in the City Division of Manila. This study is a correlational study since it looked into the relationship of the two variables: the teacher's performance and the leadership practices. Under the leadership practices are the five leadership practices of the Leadership Practices Inventory self-assessment authored by Jim Kouzes and Barry Posner such as modeling the way, inspiring shared vision, challenging the process, enabling others to act and encouraging the heart.

The correlation method of this study involves looking at the relationship between the existing variables. The 
researcher used correlation to see if the relationship of the two really exists. These variables are not under the control of the researcher. The respondents of this study were the public elementary teachers in the Division of Manila. There were a total of 200 teachers coming from the different public schools in Manila that are going to be used as the respondents of this study. The population in this study was the elementary teachers in the Division of Manila. The researcher used Multi-Stage Sampling and Purposive Sampling in identifying the sample population for the study. Multi-Stage Sampling is a sampling plan wherein the population will be divided or clustered until a smaller sampling unit in each stage. In this study, it has three stages:

$>\quad$ In the first stage, the researcher clustered all the public elementary schools in the City Division of Manila. The 81 public elementary schools were clustered according to the district location that they are located. In the City Division of Manila, the public elementary schools were clustered into six districts.

$>\quad$ The next stage in the Multi-Stage Sampling was randomly picked from two districts using the Fish Bowl Sampling. Each district has an equal chance of being included as a sample. This sampling method is easy to use especially to those small populations. The researcher randomly picked two districts. And it showed that District 3 and District 4 are the two districts that were picked.

$>\quad$ In the last stage, the researcher again randomly picked three big schools in Districts 3 and 4 using the random sampling method. After getting the three big schools, it will apply the purposive sampling to get the $20 \%$ population of each big school.

In District 3, the schools that were randomly picked were Pedro Guevarra Elementary School; Francisco Balagtas Elementary School; and Padre Burgos Elementary School. In District 4, the schools that were randomly picked were Dr. A. Albert Elementary School; Padre Burgos Elementary School; and Legarda Elementary School.

Research Instrument - The focus of the study is to know the relationship between the Five (5) Models of Leadership Inventory and the teacher's performance. The researcher uses a two-part written survey instrument as the tool for this study. Part one of the survey included the teacher's performance indicated in their Individual Performance Commitment and Review Form (IPCRF). The IPCRF has an adjectival rating of: 4.500 - 5.000 outstanding; 3.500 - 4.499 - very satisfactory; 2.500 - 3.499 - satisfactory; 1.500 - 2.499 - unsatisfactory; and below 1.499 - poor.

The second part two of the survey is to self-assess the respondents with the use of a questionnaire that was developed by James M. Kouzes and Barry Z. Posner entitled "Leadership Practice Inventory (LPI) Self-Assessment". See Appendix C. It is made up of 30 behavioral statements. The questionnaire has five leadership practices known as Five Exemplary Models of Leadership Practices such as modeling the way, inspiring a shared vision, challenging the process, enabling others to act and encouraging the heart. In every leadership practice there are six behavioral statements. The respondents will take 10 to 20 minutes to complete the self-assessment questionnaire. They will rate themselves which they believe they engage in each 30 behavioral statements. Leadership Practices Inventory (LPI) encountered meticulous criteria for psychometric testing, and because of this and including its strong reliability and validity, many people including students are confident in using the LPI to assess and be an effective leader.

Leadership practices Inventory (LPI) uses a rating scale from 1 to 10.

$$
\begin{array}{ll}
1 \text { - Almost Never } & 6 \text { - Sometimes } \\
2 \text { - Rarely } & 7 \text { - Fairly Often } \\
3 \text { - Seldom } & 8 \text { - Usually } \\
4 \text { - Once in a While } & 9 \text { - Very Frequently } \\
5 \text { - Occasionally } & 10-\text { Almost Always }
\end{array}
$$

The researcher contacted the author of the Leadership Practices Inventory (LPI) to have permission to use 
this instrument in conducting the study. She ordered and bought through their official website www.wiley.com. James Kouzes and Barry Posner are the authors of the Leadership Practices Inventory (LPI). It is one of the most widely used 360-degree leadership assessment instruments available. This questionnaire will provide the respondents an opportunity to assess and to reflect their capability and desire regarding their effectiveness and efficiency as a teacher. The Leadership Practices Inventory (LPI) and the Five Practices of Exemplary Leaders Model consistently confirms its reliability and validity for over fifteen years.

Data Gathering Procedure - The researcher secured a permit to conduct the study from the Division Office of Manila before the questionnaires were distributed to the respondents. After getting the approval signed by the Division Superintendent of Manila, another request was sent to the different principles of the teacher respondents. The researcher personally visited the different schools of the respondents and asked help from the guidance counselor and school principal to administer the questionnaires. After a week, the researcher collected all the questionnaires from the different schools that were used in this study. Moreover, retrieval of the data was done through tallying and data analytic procedures in computing the inferential test of the study.

Data Analysis - Descriptive statistics is used in this study to describe the basic features of the data. It provides simple summaries about the sample and the measures. Together with simple graphics analysis, they form a quantitative summary based on the data gathered.

\section{Results and Discussions}

The purpose of this study is to examine the relationship between the leadership practices and teacher's performance. It aims to help the teachers to assess and reflect themselves on their leadership practices. This study used the Leadership Practices Inventory (LPI) created by James M. Kouzes and Barry Z. Posner and the Individual Performance Commitment and Review Form (IPCRF) for the School Year 2017-2018. The self-inventory assessment has five leadership practices such as Model the Way, inspire a Shared Vision, Challenge the Process, Enable Others to Act and Encourage the Heart, this is called Five Practices of Exemplary Leadership Model. In every leadership practice there are six behavioral statements. In all, it has 30 behavioral statements. The results of this study are presented in this chapter. It is conducted in the City Division of Manila, wherein the respondents are the public elementary teachers of Districts 3 and 4 in the City of Manila. There are 176 teachers who participated in this study, 146 of them are female teachers and 30 are male teachers.

\subsection{What is the teacher's performance based on the Individual Performance Commitment Form (IPCRF) for}

School Year 2017-2018?

The teacher's performance based on Individual Performance Commitment Form (IPCRF) for School Year 2017-2018 is manifested in table 1 .

\section{Table1}

Frequency and percentage distribution of respondents according to their teaching performance

\begin{tabular}{|c|c|c|}
\hline Teaching Performance Rating & Frequency & Percentage \\
\hline Very Satisfactory & 170 & 96.6 \\
\hline Outstanding & 6 & 3.4 \\
\hline Total & 176 & 100 \\
\hline
\end{tabular}

As manifested in the data, the profile of the teachers in terms of their performance rating. 170 teachers obtained a rating of very satisfactory with a percentage of $96.6 \%$ and six teachers acquired a rating of outstanding with a percentage of 3.4\%. Majority of the teacher respondents attained a very satisfactory rating. Based on the Individual Performance Commitment Review Form (IPCRF) (See Appendix B, sample of IPCRF), a very satisfactory rating is the second highest rating that a teacher can achieve and the outstanding rating is the highest rating. The performance rating of the teachers was based on the Individual Performance Commitment Review Form (IPCRF) for the school year 2017-2018. 
This evaluation form is a comprehensive standard evaluation form for teachers used nationwide. It is based on the mandated DepEd Order No. 2, s. 2015 entitled Guidelines on the Establishment and Implementation of the Result-Based Performance Management System (RPMS) in the Department of Education, signed by Br. Armin Luistro FSC, former DepEd Secretary. The DepEd Order was aligned to the Department of Education's mandate, vision, mission and its core values, which is committed to continuously improve itself to better serve the Filipino learners and the community. In Roman Numeral V, Performance Cycle/Process, each personnel must have accomplished the Individual Performance Commitment Review Form (IPCRF) to reflect and evaluate their performance for one whole year: starting in April of current year and ending in March of the following year for the school-based personnel; and starting in January and ending in December for non-school-based personnel.

According to the study of Koedel et al. (2015), education agencies must design quality and effective evaluation ratings. This can affect teachers' job satisfaction as well as their performance. The more satisfied teachers are with their job, the more quality and effective education will be given to their students. In addition, this evaluation rating can be a tool to identify promoting employees who perform well on their job as a teacher. In the study of Usop et al. (2013), teachers are satisfied with their job when they feel the happiness of what they are doing. They are motivated to work and perform their duty and task as a teacher. Their job satisfaction may affect and influence their performance as well as their attitudes. And because of this, if they are happy and content with their job, it will show on their performance and produce a productive and competitive learner.

\subsection{How the leadership practices of the teachers describe using the five practices of exemplary leadership model?}

Leadership practices of the teachers described using the Five Practices of Exemplary Leadership Model is portrayed in table 2 .

\section{Table 2}

Descriptive leadership practices of exemplary leadership model in terms of model the way

\begin{tabular}{lcc}
\multicolumn{1}{c}{ Model the Way } & Weighted Mean & $\begin{array}{c}\text { Verbal } \\
\text { Interpretation }\end{array}$ \\
\hline $\begin{array}{l}\text { I set personal examples of what I expect of others. } \\
\text { I make certain that people adhere to the principles and standards } \\
\text { that have been agreed upon. }\end{array}$ & 7.60 & $\begin{array}{c}\text { Fairly Often } \\
\text { Fairly Often }\end{array}$ \\
$\begin{array}{l}\text { I follow through on the promises and commitments that I make. } \\
\text { I ask for feedback on how my actions affect other people's } \\
\text { performance. }\end{array}$ & 8.15 & 7.57 \\
$\begin{array}{l}\text { I build consensus around a common set of values for running our } \\
\text { organization. }\end{array}$ & 7.78 & Fairly Often \\
$\begin{array}{l}\text { I am clear about my philosophy of leadership. } \\
\text { Overall Level of Exemplary Leadership Model in terms of Model } \\
\text { the Way }\end{array}$ & 7.81 & Fairly Often \\
\hline
\end{tabular}

It manifested to table 2 that there is fairly often Leadership Practices of the selected teachers ranging an overall level of 7.77 in terms of Model the Way. Moreover, this result was validated support through the sub-variables pertaining to: (1) teachers set personal example of what they expect to others $(\mathrm{WM}=7.60),(2)$ teachers make certain that people adhere to the principles and standards that have been agreed upon $(\mathrm{WM}=$ 7.73), (3) teachers follow through on the promises and commitments that they make (WM $=8.15)$, (4) teachers ask for feedback on how my actions affect other people's performance (WM = 7.57), (5) teachers build consensus around a common set of values for running our organization (WM =7.78), and (6) teachers intensify clear about their philosophy of leadership (WM=7.81).

Furthermore, the results deepen the promises and commitments of the teachers in their leadership between and among the members of the education environment. However, (Mulford, 2003) stated that being a leader in a group has a lot of responsibility especially in a school wherein so many people, teachers, students, parents and 
others needed to manage and lead. Schools continuously provide a quality education to all and because of that, it needs to become a good learning organization. The leadership effectiveness depends on how the leader influences the organization. The school leaders play an important role in the development of an organization. To achieve this, recruitment, development and retention of teachers and the students' outcome must be strengthened by the school leaders. To make this happen, there are factors to be considered such as teacher's satisfaction, school effectiveness, improvement, capacity, teacher leadership, distributive leadership, organizational learning and development.

Indeed, Leaders create standards to perform and have excellence in leading others and set examples for others to follow the way. They must model the expected behavior or standard to others if they want to gain commitment and respect from them. They must clarify values and behavior and be clear in guiding these principles (Kouzes \& Posner, 2003; del Castilo, 2021).

Table 3 interpreted that selected teachers have fairly often Inspire a Shared Vision with their Practices of Exemplary Leadership having an overall level of 7.52. On the other hand, it suggests that teachers can talk about future trends that will influence how their work gets done, ranging a mean value of 7.23. In this view, an effective school leader must consider the school and its people not only his personal interests and wants. The consideration of the whole stakeholders in all the decisions and actions that needs to be addressed is very important to make the school work harmonious. The feeling of valued and belongingness in an organization can make people give their trust and loyalty to the organization. Knowing that they can share and contribute to the organization, they will remain and give their service to the school. Leadership is all about learning, from followers as well as others in leadership roles. Leaders should show a profound respect for the worth of every individual they encounter, and should integrate this practice into daily communication with fellow stakeholders. The results are likely to be positive for everyone involved.

Table 3

Descriptive leadership practices of exemplary leadership model in terms of inspire a shared vision

\begin{tabular}{lcc}
\multicolumn{1}{c}{ Inspire a Shared Vision } & $\begin{array}{c}\text { Weighted } \\
\text { Mean }\end{array}$ & $\begin{array}{c}\text { Verbal } \\
\text { Interpretation }\end{array}$ \\
\hline $\begin{array}{l}\text { I talk about future trends that will influence how our work gets } \\
\text { done. }\end{array}$ & 7.23 & Fairly Often \\
$\begin{array}{l}\text { I describe a compelling image of what our future could be like. } \\
\text { I appeal to others to share an exciting dream of the future. }\end{array}$ & 7.38 & $\begin{array}{l}\text { Fairly Often } \\
\text { I show others how their long-term interest can be realized by } \\
\text { enlisting in a common vision. }\end{array}$ \\
$\begin{array}{l}\text { I paint the "big picture" of what we aspire to accomplish. } \\
\text { I speak with genuine conviction about the higher meaning and }\end{array}$ & 7.37 & Fairly Often \\
$\begin{array}{l}\text { purpose of our work. } \\
\text { Overall Level of Exemplary Leadership Model in terms Inspire a }\end{array}$ & 7.69 & Fairly Often \\
Shared Vision & & Fairly Often \\
\hline
\end{tabular}

Many teachers can become a leader. To become one of the teacher leaders, a wide range or roles must be considered to achieve and support the school and student success. Some of these are: (a) resource provider helps by sharing instructional materials; (b) instructional specialist helps in implementing effective teaching strategies; (c) curriculum specialist lead teachers to agree on standards, follow the adopted curriculum, use common pacing charts and develop shared assessment; (d) classroom supporter help in implementing new ideas to other teachers; (e) learning facilitator share and give facilitating professional learning opportunities among staff members; (f) mentor serves as a role model, acclimate and advise new teachers about instruction, curriculum, procedure, practices and more; (g) school leader serves and shares responsibilities for the success of the school; (h) data coach to use and share the information to strengthen instruction; (i) catalyst for change; and (j) learner who continuously improve and learn his or her learning and use it to help all students achieve. (Harrison \& Killion, 2007). 
Apparently, the results overviewed support with the assessment of the teachers to the remaining sub-variables pertaining to: teachers describe a compelling image of what our future could be like $(\mathrm{WM}=7.38)$, teachers have appeal to others to share an exciting dream of the future $(\mathrm{WM}=7.65)$, teachers show others how their long term interest can be realized by enlisting in a common vision (WM =7.37), teachers can paint the "big picture" of what they aspire to accomplish (WM = 7.69), and teachers speak with genuine conviction about the higher meaning and purpose of their work $(\mathrm{WM}=7.80)$.

With this, teachers will Inspire a Shared Vision to leaders that have a vision or goals that they want to achieve for their organization. They have faith in these visions and believe that they can make extraordinary things happen. They enlist others in their common vision for the success of the entire organization. In an organization, it is a big challenge of over viewing the future of the educational leaders and the educational learning environment. Exchanging thoughts and wisdom are necessary for the full extent of the learning environment.

\section{Table 4}

Descriptive leadership practices of exemplary leadership model in terms of challenge the process

\begin{tabular}{lcc}
\hline \multicolumn{1}{c}{ Challenge the Process } & $\begin{array}{c}\text { Weighted } \\
\text { Mean }\end{array}$ & $\begin{array}{c}\text { Verbal } \\
\text { Interpretation }\end{array}$ \\
\hline $\begin{array}{l}\text { I seek out challenging opportunities that test my own skills and } \\
\text { abilities. }\end{array}$ & 7.64 & Fairly Often \\
$\begin{array}{l}\text { I challenge people to try out new and innovative ways to do their } \\
\text { work. }\end{array}$ & 7.26 & Fairly Often \\
$\begin{array}{l}\text { I actively search for innovative ways to improve what we do. } \\
\text { I ask "what can we learn?" when things don't go as expected. }\end{array}$ & 7.77 & Fairly Often \\
$\begin{array}{l}\text { I identify measurable milestones that keep projects moving } \\
\text { forward. }\end{array}$ & 7.66 & Fairly Often \\
$\begin{array}{l}\text { I take initiative in anticipating and responding to change. } \\
\begin{array}{l}\text { Overall Level of Exemplary Leadership Model in terms Challenge } \\
\text { the Process }\end{array}\end{array}$ & 7.84 & Fairly Often \\
\hline
\end{tabular}

Table 4 projected that the teachers are fairly often obtaining Challenge the Process of Leadership garnering an overall level of 7.63. However, this result was supported by the respondent's assessment to the sub-variables such as teachers seek out challenging opportunities that test their own skills and abilities (WM = 7.62), teachers challenge people to try out new and innovative ways to do their work ( $\mathrm{WM}=7.26$ ), teachers actively search for innovative ways to improve what they do. (WM = 7.77), teachers ask "what can they learn?" When things don't go as expected ( $\mathrm{WM}=7.66)$, teachers identify measurable milestones that keep projects moving forward $(\mathrm{WM}=$ $7.60)$, and teachers take initiative in anticipating and responding to change $(\mathrm{WM}=7.84)$.

In this view, it is evident that the challenge for every professional wants to grow and develop in the career that they have chosen. Professional development is the development of competence in one's profession and a process of acquiring the skills needed to improve performance in a job (Oxford Dictionary). It is about teachers learning, learning how to learn, and transforming their knowledge into practice for the benefit of their students' growth (Avalos, 2007). Many people refer to professional development as a formal education or process like graduate schools, seminars, training, workshops or conferences. But it also refers to collaborative learning among colleagues and peers (Mizell, 2010).

For teachers and school, learning is a never-ending process. It is an ongoing learning, an expanding of knowledge and skills to be effective in transferring the learning to the students. It is important for the teachers to continue their learning in order to address the needs of the students. It focuses on developing the teaching and learning skills of the teachers and also for the success of the school. There are many innovative teaching strategies that teachers can acquire in schools, training and seminars that were not learned in their college programs (Green, 2017). The continuing of professional development keeps teachers up-to-date on new research on how children learn what emerging technology tools for the classroom, new curriculum resources, and more. 
Students nowadays have a lot of access to learning. There are technologies and the internet in searching and answering a lot of questions in mind. Because of this, the teachers must be more knowledgeable enough to pace the challenging world of the students. As in all professions, teachers and even principals take years in gaining this development (Moore, 2015).

Changes never stop. In education, a lot of changes and innovations occur in learning contents, curriculum, instructional materials and methods. It is hard for the teachers who do not experience effective professional development in facing these challenges and the students will suffer from this. For this professional development to be achieved by the teachers, they need a lot of support, especially financial support. They will invest their time and money to attend graduate studies, training and seminars to develop and improve their practices and instructions. Professional development is the connection between curriculum and the implementation of education reforms and the ultimate success of reform efforts in school (DeMonte, 2013). The implementation of effective professional development to the teachers is very essential to the teaching and learning skills that will support the students' development that they need to thrive in the 21 st century. (Hammond, Hyler, \& Gardner, 2017).

Furthermore, Leaders find ways and opportunities to change, improve, innovate and grow the status quo of the organization. To achieve this, they must experiment and take risks and welcome challenges (Kouzes and Posner, 2003). They must also accept the mistakes and disappointments while taking the risks and challenges. Leaders must not be afraid and openly admit that they made mistakes (Graybeal, 2015).

\section{Table 5}

Descriptive leadership practices of exemplary leadership model in terms of enables to others to act

\begin{tabular}{lcc}
\multicolumn{1}{c}{ Enables to Others to Act } & $\begin{array}{c}\text { Weighted } \\
\text { Mean }\end{array}$ & $\begin{array}{c}\text { Verbal } \\
\text { Interpretation }\end{array}$ \\
\hline $\begin{array}{l}\text { I develop cooperative relationships among the people I work. } \\
\text { I actively listen to diverse points of view. }\end{array}$ & 8.27 & $\begin{array}{c}\text { Usually } \\
\text { Usually }\end{array}$ \\
$\begin{array}{l}\text { I treat others with dignity and respect. } \\
\text { I involve people in the decisions that directly impact their job } \\
\text { performance. }\end{array}$ & 8.94 & $\begin{array}{c}\text { Usually } \\
\text { I give people a great deal of freedom and choice in deciding how to } \\
\text { do their work. }\end{array}$ \\
$\begin{array}{l}\text { I ensure that people grow in their jobs by learning new skills and } \\
\text { developing themselves. }\end{array}$ & 8.03 & Fairly Often \\
$\begin{array}{l}\text { Overall Level of Exemplary Leadership Model in terms Enable } \\
\text { Others to Act }\end{array}$ & 8.99 & Eairly Often \\
\hline
\end{tabular}

It is interpreted in table 5 that teachers usually have a way of Enabling Others to Act with an overall level of 8.22. It means that teachers empower cooperation, the act of listening to the point of view of the others with dignity and respect for a great deal of working with one another.

Furthermore, the result intensified support through the assessment of the teachers to the sub-variable pertaining to teachers develop cooperative relationships among the people they work $(\mathrm{WM}=8.27)$, teachers actively listen to diverse points of view ( $\mathrm{WM}=8.21)$, teachers treat others with dignity and respect $(\mathrm{WM}=8.94)$, teachers involve people in the decisions that directly impact their job performance ( $\mathrm{WM}=7.90)$, teachers give people a great deal of freedom and choice in deciding how to do their work $(\mathrm{WM}=8.03)$, teachers ensure that people grow in their jobs by learning new skills and developing themselves (WM = 7.99).

With this result, Human Relations is a study of human problems arising from an organization: from the management to the employee. It maintains a good relationship for all the people of an organization wherein it addresses the needs of the management and the employees, resolves the conflict and trains the employee for the improvement of an organization. Having a more 'human' workplace, the management and the employee must create a harmonious relationship and must work cooperatively. There are many approaches and strategies that 
every organization can use to achieve this kind of relationship. Therefore, assessing the relationships of oneself as an employee to other employees and to the organization must be determined and identified. All organizations wanted to have a good relationship among all the people of the organizations, from the management to the employee. They tried their best to achieve this relationship to attain their missions and goals (Lamberton \& Evans, 2014).

Having a 'human' workplace in an organization can be achieved if there is a good human relationship. Having a big organization is so hard to handle. The importance of human relations is very essential in an organization. It is one of the foundations of a school so that it can achieve the goal of an organization. Workplace relationships provide a source of employee motivation, which is important in maintaining productivity. The relationship of me to you and to others must be developed to a good, healthy and productive relationship and for the success of the workplace. The determining and identifying the relationship of me, you and others in an organization is hard to earn. Many conflicts and misunderstandings can be faced and a lot of problems to solve. But when this is solved and addressed, a good relationship will occur (Lamberton \& Evans, 2014, p.4).

In every organization, there is a management who manages and leads its employees. As a leader, he must know the value of each and every one of his employees. He knows how to handle and approach different personalities of the people around him and knows the right approach to address the strengths and weaknesses of the organization. The need of determining and identifying is very important to know the strengths and weaknesses and know how to develop the strengths and improve the weaknesses. Establishing and maintaining a good relationship in a workplace is the key to achieve the missions and goals of an organization. Talking to each other is very important. Valuing and respecting the people can lead to reaching the goal of an organization. However, in an organization, team effort and collaboration are required to achieve greatness. Leaders could not achieve the goals alone; they need the involvement of others. They must build trust and involve others in making decisions and make each person feel belonging and love. He trusts others to accomplish the work.

\section{Table 6}

Descriptive leadership practices of exemplary leadership model in terms of encouraging the heart

\begin{tabular}{lcc}
\hline \multicolumn{1}{c}{ Encouraging the Heart } & $\begin{array}{c}\text { Weighted } \\
\text { Mean }\end{array}$ & $\begin{array}{c}\text { Verbal } \\
\text { Interpretation }\end{array}$ \\
\hline $\begin{array}{l}\text { I praise people for a job well done. } \\
\begin{array}{l}\text { I make it a point to let people know about my confidence in } \\
\text { their abilities. }\end{array}\end{array}$ & 8.57 & $\begin{array}{c}\text { Usually } \\
\text { Fairly Often }\end{array}$ \\
$\begin{array}{l}\text { I make sure that people are creatively recognized for their } \\
\text { contributions to the success of our projects. }\end{array}$ & 8.35 & Usually \\
$\begin{array}{l}\text { I publicly recognize people who exemplify commitment to } \\
\text { shared values }\end{array}$ & 7.97 & Fairly Often \\
$\begin{array}{l}\text { I tell stories of encouragement about the good works of the } \\
\text { others }\end{array}$ & 8.19 & Usually \\
$\begin{array}{l}\text { I get personally involved in recognizing people and celebrating } \\
\text { accomplishments. }\end{array}$ & 8.12 & Usually \\
$\begin{array}{l}\text { Overall Level of Exemplary Leadership Model in terms } \\
\text { Encouraging the Heart }\end{array}$ & 8.14 & Usually \\
\hline
\end{tabular}

It shows in table 6 that there is usually Leadership in terms of encouraging the Heart of the teachers with an overall level of 8.14. However, the result revealed that encouragement of the teachers about educational work is possible.

Meanwhile, it generate assessment results with the identified sub-variables pertaining to teachers praise people for a job well done ( $\mathrm{WM}=8.57$ ), teachers make it a point to let people know about their confidence in their abilities $(\mathrm{WM}=7.64)$, teachers make sure that people are creatively recognized for their contributions to the success of their projects $(\mathrm{WM}=8.35)$, teachers publicly recognize people who exemplify commitment to shared values $(\mathrm{WM}=7.97)$, teachers tell stories of encouragement about the good works of the others $(\mathrm{WM}=$ 
8.19), and teachers get personally involved in recognizing people and celebrating accomplishments (WM = 8.12).

Indeed, in every organization, there is a management who manages and leads its employees. As a leader, he must know the value of each and every one of his employees. He knows how to handle and approach different personalities of the people around him and knows the right approach to address the strengths and weaknesses of the organization. The need of determining and identifying is very important to know the strengths and weaknesses and know how to develop the strengths and improve the weaknesses. Establishing and maintaining a good relationship in a workplace is the key to achieve the missions and goals of an organization. Talking to each other is very important. Valuing and respecting the people can lead to reaching the goal of an organization.

If so, Leaders must recognize the contribution of others in achieving their vision. It is very hard, exhausting and frustrating to make the organization on top, and the leader cannot do this alone without the help of his members. A leader must believe in the abilities and talents of others, appreciate and acknowledge the accomplishments they have done to the organization.

\subsection{What significant relation exists between the Five Practices of Exemplary Leadership Model and teaching performance?}

Table 7 provides a summary table of correlation between Respondents Leadership Practices and their Teaching Performance.

\section{Table 7}

Summary table of correlation between respondents' leadership practices and their teaching performance

\begin{tabular}{lccccc}
\hline $\begin{array}{c}\text { Leadership } \\
\text { Practices }\end{array}$ & $\begin{array}{c}\text { Computed } \\
\text { Chi-Square }\end{array}$ & df & $\begin{array}{c}p \text {-Value } \\
(2 \text {-sided })\end{array}$ & Verbal Interpretation & Decision Rule \\
\hline Modeling & $22.355^{\mathrm{a}}$ & 28 & .765 & Not significant & Accept $\mathrm{H}_{\mathrm{o}}$ \\
Inspiring & $47.439^{\mathrm{a}}$ & 27 & .009 & Very significant & Reject $\mathrm{H}_{\mathrm{o}}$ \\
Challenging & $35.774^{\mathrm{a}}$ & 27 & .120 & Not significant & ${\text { Accept } \mathrm{H}_{\mathrm{o}}}^{\mathrm{a}}$ \\
Enabling & $20.903^{\mathrm{a}}$ & 25 & .698 & Not significant & Accept $\mathrm{H}_{\mathrm{o}}$ \\
Encouraging & $18.440^{\mathrm{a}}$ & 24 & .781 & Not significant & ${\text { Accept } \mathrm{H}_{\mathrm{o}}}^{*}$
\end{tabular}

As reflected in the table, the correlation between respondents' leadership practices and their teaching performance. In this study, it used Chi-Square to measure the relationship of the two variables. The $p$-value of the Chi-Square Statistic, should be less than 0.01 which is the alpha level with $95 \%$ confidence level. The data indicates that four of the Five Models of Exemplary Leadership Practices of Kouzes and Posner, which are Model the Way, Challenge the Process, Enabling Others to Act and Encourage the Heart, have no significant relationship between the leadership practice and their teaching performance. The null hypothesis that there is no significant relationship between the two variables is accepted. This means that as the teaching performance of the teachers goes higher, they do not utilize or apply the leadership practices more often, and as their teaching performance goes lower, they do not utilize these leadership practices less often.

Based on the result of the correlation between leadership practices and teaching practices, it shows that only one of Five Leadership Practices has a very significant relationship between the teacher's performance and the leadership practice which Inspires a Shared Vision. The null hypothesis has no significant relationship between the leadership practices and the teacher's performance. The result shows that the variables have a very significant relationship. This means that as the teaching performance of the teachers goes higher, they utilize or apply the leadership practices more often, and as their teaching performance goes lower, they utilize these leadership practices less often. Overall, the result shows that there is no significant relationship between the leadership practices and teacher's performance. It means that a teacher can perform well even if he/she does not often use the leadership practices. On the other hand, the high ratings of teaching performance are not a good 
indicator to measure the leadership practices of the teachers.

In the journal written by Sherman (2016), when the values of a person conflict with the organization, it is difficult to achieve the leadership practice of modeling the way. The value of the leaders can be personal but it needs to be matched and balanced with those of the organization. The team is achieving shared values, and as a leader, they are expected to set an example or model the right way so that other members will follow correctly.

In the study of Jay (2014), one of the main goals of a school is to provide and attain academic excellence to all the students. To achieve this, all the members of the school must work as one and do their best to make a positive outcome for the students' performance. They have a shared vision that they are aiming to achieve. Also, to achieve this, a school needs a good leader to develop and maintain the good quality of education that the school promised to all of his stakeholders. This leader provides direction for the school, the instructions and to its people. His leadership involves showing the employees how to work effectively and perform and complete their duties and responsibilities.

According to Oracion (2014), teacher leadership in the Philippine setting offers a real possibility of looking at school leadership through an alternative lens that challenges traditional or conventional positions of formal leadership and comfortable conformity. However, the Philippine public school will depend on the preparedness and capability of the principal and other formal teachers to lead. The confidence and capability of the principals recognizes that leadership's main role is to develop leadership in others. In this study, it recommended recognizing teacher leadership in the country's education reform agenda, encouraging teacher leaders to accept leadership work and giving attention to development programs for teacher leaders and principals.

According to Aunga and Masare (2014), the ideas and opinions of other co-workers are important. Giving them a chance to express their feelings about something should be visible to feel their belongingness to the group. Lamberton and Evans (2014), emphasize that allowing and considering the participation and the decision making of others to achieve the missions and objectives of the school. The relationship of me to you and to others must be developed to a good, healthy and productive relationship for the success of the workplace. The determining and identifying the relationship of me, you and others in an organization is hard to earn. Many conflicts and misunderstandings can be faced and a lot of problems to solve. But when this is solved and addressed, a good relationship will occur.

\subsection{Based on the findings of the study, what leadership enhancement program may be recommended to improve}

the leadership practices of the teachers?

Based on the findings of the study, it comes up with a plan that will improve and develop the leadership practices of the teachers. Table 13 shows a leadership enhancement plan to strengthen the leadership practice of the teachers. With a general objective of strengthening the leadership practices of the public elementary school teachers in the Division of Manila, this plan involves all the people in a school organization such as the principal, the master teachers and the teachers. It will be facilitated by qualified persons who are experts in their field of specialization. These persons were tapped to share their knowledge and expertise not only to the teachers but also the whole school organization to help them improve their leadership practices and their performance as well. It will run for the whole school year from June to April. It plans to improve the leadership skill for excellence and develop yourself personally.

The objectives of this plan were based on the Five Exemplary Model of Leadership Practices. The activities and strategies in each leadership practice focus on the improvement and development of each practice. $100 \%$ successful outcome is expected in every activity in the enhancement plan.

Rationale: The Leadership Enhancement Plan is a broad-based plan that will enhance the leadership practices of the public elementary school teachers in the Division of Manila. The plan comprises of programs and activities, each addressing the Five Practices of Exemplary Leadership Model which are Model the Way, Inspire a Shared 
Vision, Challenge the Process, Enable Others to Act and Encourage the Heart, which can help to improve their teaching performance to provide a quality education to the students. This plan reflects the needs of the teachers for their development and improvement of their leadership practices and has an opportunity to put them into practice.

General Objective: The purpose of this Leadership Enhancement Plan is to strengthen the leadership practices of the public elementary school teachers in the Division of Manila.

\section{Table 8}

Leadership enhancement plan

\begin{tabular}{|c|c|c|c|c|c|c|c|c|}
\hline $\begin{array}{c}\text { Leadership } \\
\text { Practice }\end{array}$ & $\begin{array}{c}\text { School } \\
\text { Improvement } \\
\text { Area }\end{array}$ & Objectives & $\begin{array}{l}\text { Activities/ } \\
\text { Strategies }\end{array}$ & $\begin{array}{l}\text { Time } \\
\text { Frame }\end{array}$ & $\begin{array}{c}\text { Persons } \\
\text { Involvement }\end{array}$ & $\begin{array}{c}\text { Budget } \\
\text { and } \\
\text { Materials }\end{array}$ & $\begin{array}{l}\text { Resource } \\
\text { Speaker }\end{array}$ & $\begin{array}{l}\text { Success } \\
\text { Indicator }\end{array}$ \\
\hline $\begin{array}{c}\text { Inspire a } \\
\text { Shared } \\
\text { Vision }\end{array}$ & \multirow[t]{2}{*}{$\begin{array}{c}\text { Leadership } \\
\text { Skills for } \\
\text { Excellence and } \\
\text { Personal } \\
\text { Development }\end{array}$} & $\begin{array}{l}\text { To visualize the } \\
\text { future by } \\
\text { imagining } \\
\text { exciting } \\
\text { possibilities and } \\
\text { engaging others in } \\
\text { a common vision. }\end{array}$ & $\begin{array}{l}\text { Express vision to others } \\
\text { through communicating at } \\
\text { the personal level. } \\
\text { Self-reflection to assess } \\
\text { self-goal or vision }\end{array}$ & $\begin{array}{c}\text { July } \\
(3-5 \\
\text { hrs per } \\
\text { Session) }\end{array}$ & $\begin{array}{c}\text { Princi-pal } \\
\text { Master } \\
\text { Tea-chers } \\
\text { All Teachers }\end{array}$ & $\begin{array}{c}\text { Professio } \\
\text { nal Fee } \\
\text { Snacks } \\
\text { Materials }\end{array}$ & $\begin{array}{l}\text { Rita A. } \\
\text { Aranda, } \\
\text { EdD } \\
\text { - Director } \\
\text { of } \\
\text { Graduate } \\
\text { School } \\
\text { National } \\
\text { University }\end{array}$ & $\begin{array}{l}100 \% \text { of } \\
\text { mutual } \\
\text { commitme } \\
\text { nt to a } \\
\text { common } \\
\text { purpose }\end{array}$ \\
\hline $\begin{array}{l}\text { Model the } \\
\text { Way }\end{array}$ & & $\begin{array}{l}\text { To clarify all the } \\
\text { shared values and } \\
\text { goals and set them } \\
\text { as an example by } \\
\text { aligning actions } \\
\text { with shared values } \\
\text { and goals. }\end{array}$ & $\begin{array}{l}\text { Staff empowerment/ } \\
\text { mentorship } \\
\text { Use analytical thinking to } \\
\text { identify areas for } \\
\text { improvement to achieve } \\
\text { the shared goals and values } \\
\text { Monitor trends advocating } \\
\text { for improvements to } \\
\text { practice policy and best } \\
\text { practices. }\end{array}$ & $\begin{array}{c}\text { Septemb } \\
\text { er } \\
(3-5 \\
\text { hrs per } \\
\text { Session })\end{array}$ & $\begin{array}{c}\text { Principal } \\
\text { Master } \\
\text { Teachers } \\
\text { All Teachers }\end{array}$ & $\begin{array}{c}\text { Professio } \\
\text { nal Fee } \\
\text { Snacks } \\
\text { Materials }\end{array}$ & $\begin{array}{l}\text { Eriberto R. } \\
\text { Astorga, } \\
\text { EdD. }\end{array}$ & $\begin{array}{c}100 \% \\
\text { clear } \\
\text { about their } \\
\text { values and } \\
\text { beliefs }\end{array}$ \\
\hline $\begin{array}{l}\text { Challenge } \\
\text { the Process }\end{array}$ & $\begin{array}{c}\text { Leadership } \\
\text { Skills for } \\
\text { Excellence and } \\
\text { Personal } \\
\text { Development }\end{array}$ & $\begin{array}{l}\text { To search and } \\
\text { seize for } \\
\text { opportunities and } \\
\text { look forward to } \\
\text { innovative } \\
\text { improvements. } \\
\text { To take risks and } \\
\text { learn from all the } \\
\text { good and bad } \\
\text { experiences. }\end{array}$ & $\begin{array}{l}\text { Build or create meaningful } \\
\text { strategies to solve the } \\
\text { problem effectively. } \\
\text { Challenge one to } \\
\text { contribute to groups. } \\
\text { Allow them to learn more } \\
\text { from others by making } \\
\text { mistakes and allow the } \\
\text { group to correct it. }\end{array}$ & $\begin{array}{c}\text { Novemb } \\
\text { er } \\
(3-5 \\
\text { hrs per } \\
\text { Session })\end{array}$ & $\begin{array}{c}\text { Principal } \\
\text { Master } \\
\text { Teachers } \\
\text { All Teachers }\end{array}$ & $\begin{array}{c}\text { Professio } \\
\text { nal Fee } \\
\text { Snacks } \\
\text { Materials }\end{array}$ & & $\begin{array}{l}100 \% \\
\text { leading } \\
\text { in the } \\
\text { face of } \\
\text { challenge } \\
\text { s }\end{array}$ \\
\hline $\begin{array}{c}\text { Enable } \\
\text { Others to } \\
\text { Act }\end{array}$ & \multirow[t]{2}{*}{$\begin{array}{l}\text { Leader-ship } \\
\text { Skills for } \\
\text { Excel-lence } \\
\text { and Personal } \\
\text { Develop-ment }\end{array}$} & $\begin{array}{l}\text { To promote } \\
\text { collaboration and } \\
\text { build trust and } \\
\text { strong } \\
\text { relationships with } \\
\text { others. } \\
\text { To motivate and } \\
\text { encourage others } \\
\text { by increasing } \\
\text { self-determination }\end{array}$ & $\begin{array}{l}\text { Develop a mentorship } \\
\text { program for those who } \\
\text { need help especially those } \\
\text { teachers who are newly } \\
\text { hired. } \\
\text { Develop teamwork skills } \\
\text { by giving other members a } \\
\text { role in the team. }\end{array}$ & $\begin{array}{c}\text { January } \\
(3-5 \\
\text { hrs per } \\
\text { Session })\end{array}$ & $\begin{array}{c}\text { Principal } \\
\text { Master } \\
\text { Teachers } \\
\text { All Teachers }\end{array}$ & $\begin{array}{c}\text { Professio } \\
\text { nal Fee } \\
\text { Snacks } \\
\text { Materials }\end{array}$ & & $\begin{array}{l}100 \% \\
\text { impleme } \\
\text { nting } \\
\text { co-operat } \\
\text { ive goals } \\
\text { and build } \\
\text { relationsh } \\
\text { ips based } \\
\text { on trust }\end{array}$ \\
\hline $\begin{array}{l}\text { Encourage } \\
\text { the Heart }\end{array}$ & & $\begin{array}{l}\text { To recognize all } \\
\text { contributions and } \\
\text { always appreciate } \\
\text { an individual's } \\
\text { excellence. }\end{array}$ & $\begin{array}{c}\text { Build a stronger } \\
\text { mentorship relationship } \\
\text { with my team leader. } \\
\text { Work on building stronger } \\
\text { relationships with } \\
\text { colleagues by recognizing } \\
\text { the contributions of others } \\
\text { to the team. } \\
\text { Engage in reflective } \\
\text { listening, small talks to } \\
\text { build rapport in a team. }\end{array}$ & $\begin{array}{c}\text { March } \\
(3-5 \\
\text { hrs per } \\
\text { Session) }\end{array}$ & $\begin{array}{c}\text { Principal } \\
\text { Master } \\
\text { Teachers } \\
\text { All Teachers }\end{array}$ & $\begin{array}{c}\text { Professio } \\
\text { nal Fee } \\
\text { Snacks } \\
\text { Materials }\end{array}$ & & $\begin{array}{l}100 \% \\
\text { encourag } \\
\text { ement to } \\
\text { other } \\
\text { member } \\
\text { to carry } \\
\text { on in } \\
\text { difficult } \\
\text { situations }\end{array}$ \\
\hline
\end{tabular}




\section{Conclusion and recommendations}

Assessing oneself regarding their effectiveness and efficiency as a teacher's leadership is very important for an organization. Their awareness of this can be their motivation to improve themselves as a leader. Also, it will help to develop and improve their school in achieving their goals. The strengths and weaknesses of leaders in an organization should be identified to address the needs and to improve the good quality to develop.

In the study, it shows that the teachers can perform well even if he/she does not utilize the leadership practices. Four out of the Five Leadership Practices of Exemplary Model have no significant relationship to the teaching performance of the teachers; therefore, the high or low rating of the teacher's teaching performance is not an indicator to assess their leadership practices. Teachers who manifest these four leadership practices such as having credibility and integrity in modeling the way; accepting and taking the risks and challenges; encouraging collaboration and strengthening others; and acknowledging and recognizing the contributions of others will not affect their performance as a teacher.

In this study, the leadership practice Inspire a Shared Vision has a significant relationship to the teaching performance of the teachers. As their performance goes higher, this leadership practice is utilized more often. At the same time, as the performance goes lower, it affects the leadership practice less often. The teacher who envisions and plans the future while others aim a shared vision can help the teaching performance of the teachers to improve (Jay, 2014). They are targeting one goal and because of this, they should perform well to achieve this goal. The organizations' goal and vision are their inspiration to perform well and enhance their skills and performance as a teacher.

Based on the conclusions, the following are recommended to address the needs and concerns of this study:

$>\quad$ The conceptualized enhancement program for teachers regarding their leadership practices can be adopted by the Educational Leaders with their Educational Environment.

$>\quad$ School Administrators and teachers should be self-motivated and committed to continually upgrade their educational and professional qualifications in participating in different courses and training/seminars that are relevant to their field of specialization.

$>\quad$ The teachers should be updated in earning more units in Continuing Professional Development packages provided by DepEd and NEAP (National Educators Academy of the Philippines).

$>\quad$ The School Administrators and teachers of the selected schools should continue to enhance their collaborative leadership skills by objectively understanding their strengths and weaknesses and by addressing performance gaps based on the lowest ratings given through respondents.

$>\quad$ School Administrators should continually seek feedback about their collaborative leadership skills from a spectrum of leaders and followers: their superiors, subordinates, peers and mentors. This researcher believes that the effective practice of collaborative leadership skills is an important factor in increasing school effectiveness.

$>$ The School Administrators should use reflective practice and to listen to the teacher's voice to maximize their level of effectiveness as leaders. All requisites for skill and competency should be included in school seminars, training and Learning Action Cells in the schools.

$>$ School Administrators should focus on boosting teacher motivation. They should discover what matters to teachers and how to best motivate them for sustained and improved level of school performance. They should be aware of varied motivators, particularly rewards such as self-respect, responsibility and a sense of accomplishment to be gained.

There is a need for school administrators and teachers to develop their collaborative leadership skills 
Leadership practice as antecedents of the teacher's performance in the City Division of Manila

using a design about professional development plans for teachers at the school level and other integrated systems for leaders and teachers' opportunities for growth and development.

$>\quad$ The conceptualized Leadership Enhancement Plan presented in this study is hereby enjoined for better results and other related further study.

\section{References}

Amy M., et al. (2011). Improving student learning by supporting quality teachers, key issues, effective strategies. Editorial Projects in Education.

Atsebeha, A. (2016). Principals' leadership styles and their effects on teachers' performance in the Tigray Region of Ethiopia. University of South Africa.

Aunga, D., \& Masare, O. (2017). Effect of leadership styles on teacher's performance in primary schools of arusha district Tanzania 2017. International Journal of Educational Policy Research and Review, 4(4), 42-52.

Avalos, B. (2010). Teacher professional development in teaching and teacher education over ten years. Centre for Advanced Research in Education. https://doi.org/10.1016/j.tate.2010.08.007

Avolio, B., Walumbwa, F., \& Weber, T. J. (2009). Leadership: Current theories, research, and future directions.

Management Department Faculty Publications. https://doi.org/10.1146/annurev.psych.60.110707.163621

Campbell, C. (2011). Leadership and its impact on supervision being an effective supervisor; Learned behavior or innate characteristic. Research Papers. Paper 54. http://opensiuc.lib.siu.edu/gs_rp/54

Darling-Hammond, L., Hyler, M. E., \& Gardner, M. (2017). Effective teacher professional development. Palo Alto, CA: Learning Policy Institute.

Darling-Hammond, L., Hyler, M., \& Gardner, M. (2017). Effective teacher professional. Development Learning Policy Institute.

del Castillo, F. (2021). Leadership: Towards equitable COVID-19 vaccination. Journal of Public Health, 43(2), 346-347. https://doi.org/10.1093/pubmed/fdab051

del Monte, J. (2013). High-quality professional development for teachers: Supporting teacher training to improve student learning. https://www.americanprogress.org/

Derivan, G. (2016). Personalizing teacher needs. George Lucas Educational Foundation.

Goewey, D. F. (2012). Examining the Kouzes and Posner leadership practices of elementary principals in central New York. Education Doctoral. Paper 9.

Graybeal, K. D. (2015). A comparison of principals' and teachers' scores on the leadership practices inventory and the Purdue teacher opinionaire. Electronic Theses and Dissertations. Paper 2482. http://dc.etsu.edu/etd/2482

Green, D. (2017). If education is going to improve, we must work on improving initial teachers. Training Hightower.

Harrison, C., \& Killion, J. (2013). Ten roles for teacher leaders. ASCD.

Hernando-Malipot, M. (2017). Teachers' performance in licensure exam declining-study. Manila Bulletin. Jay, A. (2014). The principals' leadership style and teachers performance in secondary schools of Gambella Regional State. Institute of Education and Professional Development Studies, Department of Educational Planning and Management, Jimma, Ethiopia.

Katzenmeyer, M., \& Moller, G. (2009). Awakening the sleeping giant: Helping teachers develop as leaders. Thousand Oaks, CA: Corwin Press.

Koedel, C., et al. (2015). The impact of performance ratings on job satisfaction for public school teachers. Tennessee Consortium on Research, Evaluation and Development (the Consortium) at Vanderbilt University's Peabody College.

Kouzes, J. M., \& Posner, B. Z. (2013). Leadership practices inventory (4th ed.). http://www.leadershipchallenge.com

Lamberton, L., \& Minor-Evans, L. (2013). Human relations: Strategies for success. 
Lacanin, M. E., \& Astorga, E. R., Jr.

Lazaro, G. J. (2011). Correlation of performance and leadership practices towards a teacher leadership enhancement program. SISC Kaizen.

Magsayo, Y. B. (2009). The influence of teacher quality on students' performance. ejournals.ph, 5(1).

Mizell, H. (2010). Why professional development matters. Learning Forward. http://www.learningforward.org

Moore, D. (2015). Master teachers as instructional leaders: An instrumental case study. Liberty University.

Mugavin, B. (2018). Enable others to act: Leadership is about relationships. http://www.flashpointleadership.com

Mulford, B. (2003). School leaders: Changing roles and impact on teacher and school effectiveness. Professor and Director Leadership for Learning Research Group Faculty of Education University of Tasmania.

Nanjundeswaraswamy, T. S., \& Swamy, D. R (2014). Leadership styles Department of industrial engineering and management, JSS Academy of Technical Education, Bangalore. Advances In Management, 7(2).

Oracion, C. (2014). Teacher leadership in public schools in the Philippines. Institute of Education, University of London

Sherman, R. O. (2016). Modeling the way as a leader. http://www.emergingrnleader.com

Stronge, J. H., Richard, H. B., \& Catano, N. (2008). Qualities of effective principal.

Sun-Star Pampanga Press Reader. (2017). Master teachers providing mastery teaching. https://www.pressreader.com

Usop, Annierah M., et al. (2013). The significant relationship between work performance and job satisfaction in the Philippines. School of Social Sciences, Universiti Sains Malaysia, Pulau Pinang, Malaysia

Zhang, D. (2008). The effects of teacher education level, teaching experience, and teaching behaviors on student science achievement. All Graduate Theses and Dissertations. 155.

https://digitalcommons.usu.edu/etd/155 